\title{
HUMAN RESOURCES MANAGEMENT PRACTICES \& EMPLOYER BRANDING COMPARATIVE STUDY BETWEEN SERVICE AND PRODUCT SECTOR
}

\author{
Mohamed Wahba $^{1^{\star}}$ and Dalia Elmanadily ${ }^{2}$ \\ ${ }^{1}$ Assist. Prof. Dr., Arab Academy for Science, Technology \& Maritime Transfer, Egypt, \\ m_wahba2003@hotmail.com \\ ${ }^{2}$ Master of Business Administration Student, Alexandria University, Egypt, \\ delmanadily@yahoo.com \\ ${ }^{*}$ Corresponding author
}

\begin{abstract}
This study is an exploratory study aims to investigate the impact of human resources management practices on employer branding personality by comparing between Pharmaceuticals industry and Telecommunication sector in Egypt. The survey was based on corporate character scale indicators that had been modified and used locally \& HRM practices. The paper surveyed literature review of the employer branding (EB) concept and recruitment, training, reward system, performance appraisal and career management in the pharmaceutical and telecommunication sector overview in Egypt. The study findings human resources management practices impacts employer branding as illustrated through paper. Which, deeply interwoven and opens up new questions to be explored by future research identified through paper.
\end{abstract}

Keywords: HRM, Employer branding, Pharmaceutical industry, Telecommunication sector.

\section{INTRODUCTION}

Today's business environment is changing at a high pace and so is the climate of the labor market (c.f. Buck \& Dworschak 2003; Dew-Becker \& Gordon 2008; Gaddam 2008). In 2001 McKinsey \& Co stated in their report "War for Talent" that company are facing a difficulty in attracting and retaining great talents and that this will continue for at least two more decades. The brand is considered one of the most important and valuable assets of a company (Backhaus \& Tikoo, 2004). To most people a brand is directly connected to the company name, the products, services and the specific logotype. However, branding can also be used as a part of Human Resource Management (HRM) in order to attract new employees and to retain already employed members of the firm (Kunerth \& Mosley, 2011). When applying branding to HRM, the concept is entitled "Employer Branding" (EB) (Backhaus \& Tikoo, 2004) and the connection between the two concepts, HRM and EB, has been established. In 2001 the Conference Board made a report addressing the concept of EB where they compared the corporate- and employer branding methods. Some key findings from the report are that EB is strongly connected to HRM in transactional aspects, that EB is on a rise and companies were concentrating branding efforts towards employees, instead of solely towards the corporate brand as before. The report defines Human Resources (HR) and Senior Management teams as key players and their decisions as highly influential on a strategic level, whereas the actual implementation relies primarily on the individual2. The HR Executives who were a part of the study identified their goals to be recruiting and retaining employees, helping 
employees to internalize the company's values and to become a top of mind employer (The Conference Board 2001:10). This report was published in 2001, and guidelines concerning EB were starting to contrive, but the report showed that 56 percent of the responding HR executives did not believe they had an employer brand. This in contrast to the finding of many companies using an EB strategy, but they just did not know the name of it.

As stated, EB in the context of human HRM is a relatively recent phenomenon, and the amount of empirical research can definitely be seen as insufficient. Most of the research concerns the fact that EB is important, and should be implemented in HRM (Barrow, 2008; Gaddam, 2008; Maxwell \& Knox, 2009). But little empirical research has been done to show how EB is actually applied in organizations, and to completely understand the phenomenon of EB empirical contributions are necessary. The proposition is enhanced by recommendations made by Foster, Punjaisri and Cheng (2010) who claim that further empirical studies, especially qualitative case studies, must be taken in order to explore the activities of $H R$, EB and the link between the two. Also previous studies concentrated on employee attraction and retention not the other HRM practices.

So this study aimed to investigate the impact of human resource management practices on employer branding personality among organizations in Pharmaceuticals and Telecommunication industry in Egypt. The rest of the paper is structured as follows: Section two discusses the relevant literature. Section three presents research methodology, and data collection. Section four discusses the results and analysis of this investigation. Finally, section5: completes this paper by outlining limitations\& recommendations for future research.

\section{THEORETICAL BACKGROUND}

\subsection{Human Resource Management (HRM) Practices}

HRM practices have been identified in several aspects. Schuler and Jackson (1987) defined HRM practices as a system that attracts, develops, motivates, and retains employees to ensure the effective implementation and the survival of the organization and its members. Besides, HRM practices are also conceptualized as a set of internally consistent policies and practices designed and implemented to ensure that a firm's human capital contributes to the achievement of its business objectives (Delery \& Doty, 1996). Likewise, Minbaeva (2005) viewed HRM practices a set of practices used by organizations to manage human resources through facilitating the development of competencies that are firm specific, produce complex social relation and generate organization knowledge to sustain competitive advantage. Against this backdrop, we concluded that HRM practices relate to specific practices, formal policies, and philosophies that are designed to attract, develop, motivate, and retain employees who ensure the effective functioning and survival of the organization. Among the main approaches to develop HRM: - universalll or -best practicell approach (Huselid, 1995); strategic HRM practices approach (Delery \& Doty, 1996); contingency approach (Dyer, 1985; Schuler, 1989); and configuration approach (Wright \& McMahan, 1992), review of the literature demonstrates five common practices that have been consistently associated with innovation, encompassing performance appraisal, career management, reward system, training, and recruitment (Gupta \& Singhal, 1993; Jiménez-Jiménez \& Sanz-Valle, 2005; Kydd \& Oppenheim, 1990; Laursen \& Foss, 2003; Shipton, Fay, West, Patterson \& Birdi, 2005).

\subsection{Employer Branding}

Since it was first coined in 1990 by Tim Ambler and Simon Barro, as a way of combining branding techniques with human resource practices, employer branding has massively extended both in research and in the number of companies applying it (Barrow \& Mosley, 2005). Employer branding is anchored in the resource based view, recognizing that human capital is vital for organizational success (Backhaus \& Tikoo, 2004). The increased awareness and application of the concept, however, is highly contributed to past, current and future shortage of these talented employees. With a scarce talent pool, organization will apply for candidates (use employer branding) and not the other way around (Dahlström, 2011). Whereas the past shortage of talent was rooted on in the economic boom and subsequent low unemployment rates, today's shortage is caused by other influences. Today's knowledge economy sets forth two main factors contributing to the current and especially future shortage of talented employees, namely demographic and sociological changes. Demographically, larger generations of employee are soon to retire and the generations taking over are significantly smaller. Sociologically, there is a need for technology, engineering and other science - related scholars, but unfortunately not enough are educated within this area. Further, younger generation employees tend to change jobs much more frequently, which challenge organizations in terms of retaining key employees (Lodberg, 2011). Especially, the knowledge-based organizations need the talented employees, as these are among the organization's most valuable asset and can be regarded as a competitive advantage (Ewing et al. 2002). Thus, 
a shortage of talented employees combined with organization's need for them has created a "war for talent", which is the main contributor in the increased application and recognition of employer branding as an organizational discipline. Kotler (1991) defines a brand as "a name, term, sign, symbol, or design, or a combination of them which is intended to identify the goods and services of one seller or group of seller and to differentiate them from those of competitors"(Kotler, 1991:442).

The definition has primarily been used to describe product brands and the consumer's relationship to the focal product brand (Mosley, 2007). But according to recent marketing literature a brand has great impact on the company as an employer and how external stakeholders identify the organization, the corporate brand and the firm as a future workplace (Davies, 2008; Foster et al., 2010; Gaddam, 2008). There is a clear emotional relationship between the employer and the employees based on brand image (Davies, 2008; Gaddam, 2008).According to Morocko and Uncles (2008) branding and EB are closely related. What characterizes a strong brand is mostly consistent with successful employer brands. The first article regarding the subject of EB, "The Employer Brand", was published in 1996 by Ambler and Barrow, where they define the concept as "the package of functional, economic and psychological benefits provided by employment, and identified with the employing company"(Ambler \& Barrow, 1996:186). The research by Backhaus and Tikoo (2004) contributed to a further conceptualizing of the phenomena by creating a theoretical framework and they define EB as "the process of building an identifiable and unique employer identity" and the employer brand as "a concept of the firm that differentiates it from its competitors" (Backhaus \& Tikoo, 2004:502). According to Sullivan (2004:1) employer branding is as "a targeted, long-term strategy to manage the awareness and perceptions of employees, potential employees, and related stakeholders with regards to a particular firm". Rosethorn's definition from the article: "the employer keeping faith with the deak "(2009): CIPD (2010) has also defined employer branding as ".... set of attributes and qualities - often intangible- that makes an organization distinctive, promises a particular kind of employment experience, and appeals to those people who will thrive and perform best in its culture". Employer branding is the development and communication of an organization's culture as an employer in the market place" (Mandhanya \& Maitri.2010). "An employer brand is an essence the two-way deal between an organization and its people-the reason they choose to join and the reason they choose-and are permitted-to stay. Martin et al. (2011:3618) further developed the concept and define it as "a generalized recognition for being known among key stakeholders for providing a high-quality employment experience, and a distinctive organizational identity which employees value, engage with and feel confident and happy to promote to others". Rosethorn, as well as Backhaus and Tikoo view Employer Branding as a competitive advantage whilst Ambler and Barrow, in their definition, focuses on Employer Branding rather as a tool to streamline the management and the executives. Rosethorn and Ambler and Barrow describes the employer brand as something that creates an impression of the company as an employer while Rosethorn sees it as an identity maker for the company in its role as employer. Evidently, there are a number of Different views on how to use employer branding and what results to expect but there is not yet one specific, accepted definition of the term. Common features of the definitions are the unique identity and values of the firm that are utilized to communicate how the firm differentiates as an employer. Based on the research presented EB is here defined as "a strategy of internal and external communication of the unique attributes that establishes the identity of the firm as an employer and what differentiates it from others, with the aim of attracting and retaining potential and current employees". Employer branding has been introduced as a method of enhancing retention by making the promise of employment (brand promise) so distinctive and superior to the ones of competitors that the employee would not consider switching (Taylor,2002). It could be considered as a tool that aims to enhance the entire experience by increasing job satisfaction, organizational commitment, engagement, enhancing organizational culture, and defines the psychological contract throughout the employment life cycle.

The effects of a brand are often referred to as its "equity", rooted in the customer's knowledge about the brand. Two factors contribute to brand knowledge :(1) awareness; and (2) image (Keller, 1993).

Awareness is not at issue for existing employees and so the focus in this paper is therefore on image. Brand image concerns the associations held of a brand in memory; and brand personality, the projective technique used here, is one measure of these (Keller, 1998). Brand personality, the human associations we make with a brand, is a way of obtaining a holistic view of a brand's associations by using the metaphor of brand as person and applying the equivalent of a personality test to the brand. Two such measures have been developed to measure employee views (Davies et al.

2002, 2004; Slaughter et al., 2004) using human personality traits, similar to those used in assessing the personality of an individual. For example one corporate brand may be described as being more "honest" or more "daring" than another. The approach forms part of the psychological tradition, that languages develop groups of adjectives to describe the most important differences between significant objects. We personify brands, and a similar but not identical list of adjectives that we use to describe people exists for brand personality (Caprara et al., 2001).Corporate character, defined as how a stakeholder distinguishes an 
organization, expressed in terms of human characteristics, is a multidimensional construct, and its measurement scale has five main dimensions: competence, agreeableness, enterprise, chic, and ruthlessness (see Table 1).

The competence dimension could be important increasing satisfaction for both employees and customers, because organizational effectiveness is a major signal a company gives to the market (Brown and Dacin 1997).Employees will be pleased to be associated with a reliable, leading organization. Job security, for example, has a positive effect on employee satisfaction, while perceived job Insecurity will cause dissatisfaction and promote labor turnover (Arnold and Feldman 1982).

The agreeableness dimension includes trust, which has strong links to customer Satisfaction with companies, including those in the retail sector (Deepak, Singh, and Sabol 2002). Retail customers value the helpfulness, friendliness, and fairness of treatment by frontline staff members (Westbrook 1981).Agreeableness is important for employees, because trust is significantly correlated with job satisfaction and organizational commitment (Pillai, Schreisheim, and Williams1999). Differences in how employees perceive organizational justice (fairness in pay, decision making, and treatment) explain differences in their satisfaction (e.g., Price and Mueller 1986). The perceived fairness of the application of pay and promotion rules is a key predictor of salesperson job satisfaction (Dubinsky and Levy 1989). The enterprise dimension includes items such as "innovative" and "up to date." Because the retail sector is typified by constant change (Godley2003), enterprise should be relevant to market success. Chic dimension concerns organizational prestige, employees' views of how outsiders view their companies (Mael and Ashforth 1992.

Table 1: Corporate Brand Characteristics

\begin{tabular}{lllll}
\hline Agreeableness & Enterprise & Competence & Chic & Ruthlessness \\
\hline Cheerful & Cool & Reliable & Charming & Arrogant \\
Pleasant & Trendy & Secure & Stylish & Aggressive \\
Open & Young & Hardworking & Elegant & Selfish \\
Straightforward & Imaginative & Ambitious & Prestigious & Inward-looking \\
Concerned & Up to date & Achievement-oriented & Exclusive & Authoritarian \\
Reassuring & Exciting & Leading & Refined & Controlling \\
Supportive & Innovative & Technical & Snobby & \\
Agreeable & Extravert & Corporate & Elitist & \\
Honest & Daring & & & \\
Sincere & & & & \\
Trustworthy & & & & \\
Socially responsible & & & &
\end{tabular}

Source: Davies et al. (2004)

There is limited literature to guide expectations on what aspects of brand personality might be most influential with employees and, in the absence of any clear direction, a more exploratory approach was adopted in the following empirical study.

Hence the hypothesizes will be as follows:

Hypothesis1: Recruitment practices positively impacts employer brand in both sectors

Hypothesis2: Training practices positively impacts employer brand in both sectors

Hypothesis3: Rewarding system positively impacts employer brand in both sectors

Hypothesis4: Performance appraisal practices positively impacts employer brand in both sectors

Hypothesisr5: Performance appraisal practices positively impacts employer brand in both sectors

Hypothesisr6: Career management practices positively impacts employer brand in both sectors

\section{METHOD}

\subsection{Study Type}

This research can be considered as explanatory from purpose perspective. 


\subsection{Study Population and Sampling}

The study population consists of two samples of the Pharmaceutical market sector\& telecommunication sector in Egypt, for the difficulty of measuring the population as whole we selected a sample of 369 employees working in 9 organizations from sector for the first sector and 390 employees working in 10 organization from the second sector. The sample size was estimated according to (Tabachnick \& Fidell, 2007) formula.

\section{$\mathrm{N}>50+8 \mathrm{M}$}

$\mathrm{N}=$ number of participants

$M=$ no. of IVs

$\mathrm{N}>50+5^{\star} 9$

$\mathrm{N}>95$

\subsection{Questionnaire and Reponses Rate}

The study instrument is a questionnaire consists of 3 parts: 1 st part: Consists of 43 statements measured corporate brand personality, 2nd part measured human resources management practices, 3rd demographic information for the sample. The statements are assessed by using Likert scale of five points scale ranging from 1 "highly agree" to 5"highly disagree". The Corporate Character Scale (Table I), was used to measure the managers' brand associations. (Davis, 2008) HRD was measured with five practices: recruitment, training, reward system, performance appraisal and career management. (Argwala, 2003)

Cronbach's alpha coefficient was applied to estimate the reliability of studied variables, where alpha values reveal the reliability and the internal consistency between the selected dimensions of the studied variables. For the corporate brand personality the agreeableness subscale consisted of 12 items $(\alpha=.776)$,the enterprise subscale consisted of 9 items $(\alpha=.785)$,competence subscale consisted of 8 items ( $\alpha=.780)$, chic consisted of 8 items $(\alpha=.783)$, ruthlessness subscale consisted of 6 items $(\alpha=.820)$. While for the human resources management practices the recruitment subscale consisted of 3 items $(\alpha=.777)$, training subscale consisted of 5 items $(\alpha=.758)$, reward subscale consisted of 10 items ( $\alpha=.777)$, performance appraisal subscale consisted of 6 items $(\alpha=.0 .793)$, and career management subscale consisted of 3 items.Cronbach's alpha for the 5 corporate brand personality items and human resources management practices 5 items were .805 and .797 respectively which are highly reliable.

Table 2: Reliability Analysis

\begin{tabular}{|l|l|}
\hline Variable & Cronbach's Alpha \\
\hline Agreeableness & .776 \\
\hline Enterprise & .785 \\
\hline Competence & .780 \\
\hline Chic & .783 \\
\hline Ruthlessness & .820 \\
\hline Recruitment & .777 \\
\hline Training & .758 \\
\hline Rewarding system & .777 \\
\hline Performance appraisal & .795 \\
\hline Career management & .805 \\
\hline
\end{tabular}

The selected sample was a convenience sample of 369 employee working for organizations in Pharmaceutical industry in Egypt, the sample was as follows:79.4\% males,20.6\% females, $12.7 \%$ of sample aged in range 26 30 years, $33.3 \%$ of sample aged in range $30-40$ years, $33.3 \%$ of sample aged in range $41-45$ years, $18.8 \%$ of

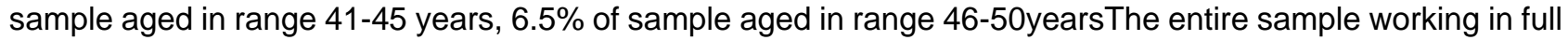
time jobs, $88 \%$ of the sample had working experiences $16-20$ years and $12 \%$ had working experience more than 20 years. The entire sample married and has children.75\% of the sample had bachelor degree in commerce and law, 25\%had master. For Telecommunication sector the selected sample was a convenience sample of 390 employee working for organizations in Telecommunications sector in Egypt, the sample was as follows: $78.3 \%$ males, $21.7 \%$ females, $26.2 \%$ of sample aged in range $26-30$ years, $32.2 \%$ of sample aged in range $30-40$ years, $30.4 \%$ of sample aged in range $41-45$ years, $9.9 \%$ of sample . The entire sample working in full time jobs, $78 \%$ of the sample had working experiences $16-20$ years and $22 \%$ had working experience more than 20 years. The entire sample married and has children.78.5\% of the sample had bachelor degree in 
commerce and law, $21.5 \%$ had master. The study conducted in 3 months, the survey yielded a total of $759(84.1 \%)$ \& returned questionnaires 191 from the whole sample

\subsection{Data Analysis Technique}

SPSS 16 software was used for the analysis of data, according to the study question: What is the impact of human resources management practices on the organizations employer brand? Which was leaded to use the regression analysis method to build the model through which Employer branding is tested to check their significance and impact on employer brand? But it was found that there are some variables are not significant, which means that their impact disappears in the presence of other variables. So stepwise regression procedure was employed to ascertain the proposed relationships between the independent variables and the dependent variable as will be seen in the next section.

\section{FINDINGS}

\subsection{Correlation Coefficient}

Correlation coefficient was performed to assess the relationship between the study variables as mentioned in table ( 3 ) it is noted that there is a significant strong between EB and HRM practices, in service sector while in product sector as seen in table(4) there is non-significant weak relationship between the variables .

Table 3: EB \& HRM practices-service sector: Correlations $(\mathrm{N}=369)$

\begin{tabular}{|c|c|c|c|c|c|}
\hline Variables & 1 & 2 & 3 & 4 & 5 \\
\hline EB & - & & & & \\
\hline Recruitment & $.495^{\star \star \star}$ & - & & & \\
\hline Training & $.607^{\star \star \star}$ & $.791^{\star \star \star}$ & - & & \\
\hline Reward & $.685^{\star \star \star}$ & $.599^{\star \star \star}$ & $689^{* \star \star}$ & - & \\
\hline performance & $.313^{* \star *}$ & $.194^{* *}$ & $261^{* * *}$ & $.598^{* * *}$ & - \\
\hline Career management & $.275^{\star \star \star}$ & $.238^{* * *}$ & $.309^{* \star *}$ & $.476^{\star * *}$ & $.781^{* * *}$ \\
\hline
\end{tabular}

Table 4: EB \& HRM practices-product sector: Correlations $(N=390)$

\begin{tabular}{|l|c|c|c|c|c|}
\hline Variables & 1 & 2 & 3 & 4 & 5 \\
\hline EB & - & & & & \\
\hline Recruitment & .069 & - & & & \\
\hline Training & .086 & $.872^{* * *}$ & - & & \\
\hline Reward & .049 & $.759^{\star * *}$ & $.474^{\star * *}$ & - & \\
\hline performance & .046 & $.474^{\star * *}$ & $.664^{\star * *}$ & .000 & - \\
\hline Career management & .050 & $.234^{* * *}$ & $.483^{* * *}$ & -.019 & $.131^{* *}$ \\
\hline
\end{tabular}

\subsection{Regression Analysis and Model}

A multiple regression was performed in order to assess if the human resources management practices (HRM) significantly predicted employer branding (EB).

The results of the regression indicated the following:

As mentioned in table (5) the results of regression indicated that the human resources management practices (HRM) explained $51.5 \%$ of employer branding in service sector $(R 2=0.51, F(1,4.404), p<.01)$. It was found that reward system significantly predicted $\mathrm{EB}(\beta=.592, p<.01)$ as did training $(\beta=-.255, p<.01)$.

Table 5: Summary of Stepwise Regression Analysis for Variables Predicting employer brand in service sector $(\mathrm{N}=369)$ 


\begin{tabular}{|l|l|l|l|}
\hline \multirow{2}{*}{ Variable } & \multicolumn{3}{|c|}{ Model 1 } \\
\cline { 2 - 4 } (Constant) & \multicolumn{1}{|c|}{$B$} & \multicolumn{1}{|c|}{$S E B$} & $\beta$ \\
\hline Recruitment & 1.467 & .090 & \\
\hline Training & -.019 & .029 & -.039 \\
\hline Reward & .165 & .043 & .255 \\
\hline performance & .497 & .054 & .592 \\
\hline$R^{2}$ & -.059 & .028 & -.100 \\
\hline$F$ & .510 & & \\
\hline
\end{tabular}

\section{CONCLUSION}

From the results analysis, it concluded that human resources management practices have impacts employer brand in services sector, while in product sector the relation is non-significant. In service sector the employer brand is more explained by training and rewarding practices, which may increase the sector responsibilities to improve and develop rewarding and training programs, satisfy the employees and enhance the organizational performance.

With regard to the product sector the relationship weak or does not exist, this result might be caused because the routine and automation nature of manufacturing process on opposite of service sector.

With regard to limitations faced this study firstly: survey collection problems because it was difficult to collect the whole sample. Second, the scarcity of the previous study in this topic to support the structure of the study.

For future research points the researchers must focus on the EB as a new phenomenon \&its sequences and consequences in HRM context

\section{REFERENCE LIST}

Aggerholm, H. K., Andersen, S. E., \& Thomsen, C. (2011). "Conceptualising employer branding in sustainable organisation"s. Corporate Communications: An International Journal, 16 (2).

Ambler, T., Barrow, S. (1996). "The Employer Brand", Journal of Brand Management. 4 (3).

Arnold, H. J. and Feldman, D. C. (1982). "A Multivariate Analysis of the Determinants of Job Turnover." Journal of Applied Psychology, 67.

Backhaus, K. Tikoo, S. (2004). "Conceptualizing and Researching Employer Branding". Career Development International. 9 (5).

Barrow, S. (2008). "A Brand New View". People Management, February.

Barrow, S., Mosley, R. (2005). The Employer Brand. West Sussex: John Wiley \& Sons Ltd.

Beardwell J and Claydon T. (2010). HRM A Contemporary Approach. Harlow: FT Prentice Hall.

Bierwirth A. (2003). Die Führung der Unternehmensmarke. Frankfurt am Main: Peter Lang.

Buck, H. \& Dworschak, B. (eds.) 2003. "Ageing and work in Europe.Strategies at company level and public policies in selected European countries". Demography and Employment. Öffentlichkeits- und Marketingstrategie demographischer Wandel.

Davies, G. (2008). "Employer Branding and its Influence on Managers". European Journal of Marketing, 42 (5).

Dew-Becker, I. \& Gordon, R.J. (2008). The Role of Labor Market Changes in the Slowdown of European Productivity Growth. NBER Working Paper No. 13840.

Dubinsky, Alan J., and John M. Gwin (1981). "Business Ethics: Buyers and Sellers". Journal of Purchasing and Materials Management. 17 (Winter).

Edwards, M. R. (2010). "An Integrative Review of Employer Branding and OB Theory”. Personnel Review. 39 
(1-2).

Ewing, M.T., Pitt, L.F., de Bussy, N.M. \& Berthon, P. (2002). "Employment Branding in the Knowledge Economy". International Journal of Advertising. 21 (1).

Foster, C., Punjaisri, K., Cheng, R. (2010). "Exploring The Relationship Between Corporate, Internal and Employer Branding", Journal of Product \& Brand Management. 19 (6).

Gaddam, S. (2008). "Modelling Employer Branding Communication: The Softer Aspect of HR Marketing Management", The Icfai Journal of Soft Skills. 2 (1).

Heger, B. (2007). "Linking the Employment VP (EVP) To Employee Engagement and Business Outcomes: Preliminary Findings from a Linkage Research Pilot Study". Organization Development Journal. 25 (2).

Huczynski, A.A. and Buchanan, D.A. (2007). Organizational Behaviour. Harlow Essex: FT Prentice Hall.

Kimpakorn, N. and Tocquer, G. (2005). "Employer Brand Equity: Employee Contribution to Service Brand Equity'. SERVSIG Research Conference, 2nd - 4th June 2005, Singapore.

Kotler, P. H. (1991). Marketing Management: Analysis, Planning, and Control, 8th ed. Englewood Cliffs. NJ: Prentice-Hall. Inc.

Kunerth, B. and Mosley, R. (2011). "Applying Employer Brand Management to Employee Engagement", Strategic HR Review. 10 (3).

Lievens, F. and Highhouse, S. (2003). "The Relation of Instrumental and Symbolic Attributes to a Company's Attractiveness as an Employer". Personnel Psychology. 56.

Lodberg, Ralf. (2011). "Employer Branding. På opdagelse i en ny branding-disciplin”. In Håndbog i strategisk public relations. Red. Henrik Merkelsen. Samfundslitteratur, 2011. 2. Edition. Pp. 157-178.

Mael, F., \& Ashforth, B. E. (1992). "Alumni and Their Alma Mater: A Partial Test of the Reformulated Model of Organizational Identification". Journal of Organizational Behaviour, 13.

Mandhanya, Y. and Maitri, S. (2010). "Employer Branding: A Tool for Talent Management". Global Management Review, 4 (2) [online]. Available from: Business Source Complete at http://search.ebscohost.com/ [Accessed 28.3.2011].

Martin, G., Gollan, P. and J., Grigg, K. (2011). "Is There A Bigger And Better Future for Employer Branding? Facing Up to Innovation, Corporate Reputations and Wicked Problems in SHRM". The International Journal of Human Resource Management. 22 (17).

Minchingotn, B. and Thorne, K. (2007). "Measuring the Effectiveness of Your Employer Brand". Human Resources Magazine. 12 (4).

Moroko, L., and Uncles, M. D. (2008). "Characteristics of Successful Employer Brands", Journal of Brand Management. 16 (3).

Mosley, R. (2007). "Customer Experience, Organizational Culture and the Employer Brand", Journal of Brand Management, 15 (2).

Pillai, R. and Williams, E. A. (2004). "Transformational Leadership, Self-efficacy, Group Cohesiveness, Commitment, and Performance". Journal of Organizational Change Management, 17 (2).

Rosethorn, Helen (2009). Origins - Two Roots to the Family Tree.The Employer Brand-Keeping Faith with the Deal. Bernard Hodes Group Gowan Publishing pg 3-16.

Sullivan, J. (2004). "Eight Elements of A Successful Employment Brand", ER Daily, 23February. Retrieved 2012-11-13 from http://www.ere.net/2004/02/23/the-8-elements-of-asuccessful-

Tabachnick, B. G. and Fidell, L.S. (2007). Using Multivariate Statistics. Boston: Pearson Education.

Taylor, S. (2010). Resourcing and Talent Management. London: Chartered Institute of Personnel and Development

Watson G. and Reissner S. (2010). Developing Skills for Business Leadership. London: CIPD. 